\title{
Absence of Y specific DNA sequences in two siblings with $46 \mathrm{XX}$ hermaphroditism
}

\author{
J RAINE, M E ROBERTSON,* S MALCOLM, ${ }^{*}$ H HOEY, AND D B GRANT \\ Hospital for Sick Children and *Mothercare Department of Paediatric Genetics, Institute of Child Health, \\ London
}

SUMMARY We report two siblings with $46 \mathrm{XX}$ hermaphroditism in whom we were unable to show the presence of $Y$ specific DNA sequences using the DNA probes Y-190, GMGY-7, pHY2.1, pDP34, and $27 \mathrm{a}$. We conclude that an autosomal or $\mathrm{X}$ chromosome gene mutation is the most likely mechanism of inheritance in this family with $46 \mathrm{XX}$ hermaphroditism.

DNA probes for regions of the $Y$ chromosome have led to identification of $Y$ specific DNA in 46XX and 45XO males, and to the presence of small deletions of the short arm in 46XY females with gonadal dysgenesis. ${ }^{1}$ Thus the discordance between karyotype, phenotype, and gonadal histology can be explained by invoking translocation or deletion of a critical segment of the $Y$ short arm, which carries male determining information, the so called testis determining factor. Recently a candidate gene for testis determining factor has been isolated. ${ }^{2}$

We describe two siblings who are 46XX hermaphrodites and in whom we were unable to identify the presence of $Y$ derived DNA using five different $\mathrm{Y}$ specific DNA probes.

\section{Case reports}

CASE 1

Case 1 was the first child of unrelated parents. Ambiguous genitalia with hypospadias, a bifid scrotum, and bilateral scrotal gonads were noted at birth. Investigations showed a $46 \mathrm{XX}$ karyotype. Three injections of human chorionic gonadotrophin (1000 units) at 3 months of age resulted in a rise in plasma testosterone from $4.1 \mathrm{nmol} / 1$ to $6.0 \mathrm{nmol} / 1$. Laparotomy showed no Mullerian structures. A gonadal biopsy specimen showed bilateral ovotestes, and gonadal fibroblast chromosomes were 46XX. Because of the well formed male external genitalia, the absence of female internal genitalia, and the plasma testosterone response to human chorionic gonadotrophin it was decided to rear the child as a male. At 3 years of age the ovarian component of the ovotestes was excised and the hypospadias repaired.

CASE 2

Case 2 was the second child in the family. His external genitalia were similar to those of his brother, as were the findings at laparotomy. Chromosome analysis showed a 46XX karyotype. Three injections of human chorionic gonadotrophin (1000 units) produced a rise in plasma testosterone from $2.0 \mathrm{nmol} / 1$ to $5.2 \mathrm{nmol} / \mathrm{l}$. This child has also been raised as a male and had his hypospadias repaired and the ovarian component of his ovotestes resected at 4 years of age.

The mother of both children is healthy; the father is said to be healthy, but was not available for study.

\section{Methods}

DNA was extracted from $10 \mathrm{ml}$ blood from each patient by standard methods. $5 \mu \mathrm{g}$ DNA was digested with appropriate restriction endonuclease (Northumberland Biologicals) using buffer provided by the manufacturer. DNA was separated by electrophoresis on $\mathbf{0 . 8 \%}$ agarose gel and transferred to a nylon filter (Hybond $\mathrm{N}$ Amersham) by blotting. The filters were hybridised for 16 hours at $65^{\circ} \mathrm{C}$ at a final salt concentration of $0.6 \mathrm{M}$. The probes were labelled by the random priming method and added to the hybridisation solution at a concentration of $10^{6} \mathrm{dpm} / \mathrm{ml}$. After hybridisation, filters were washed with sodium chloride/sodium citrate solution at $65^{\circ} \mathrm{C}$ to remove unhybridised probe, then exposed to Kodak XAR5 autoradiographic film with intensifying screens at $-70^{\circ} \mathrm{C}$ for one to five days. Before reuse filters were washed with boiling $10 \mathrm{mM}$ TRIS, pH 8.

\section{HYBRIDISATION PROBES}

$\mathrm{Y}-190^{3}$ and $\mathrm{GMGY}-7^{3}$ are highly repetitive probes from the short arm of the $\mathrm{Y}$ chromosome. pHY2.1 (DYZ2) is a very highly repetitive probe from the long arm of the $Y$ chromosome. pDP34 is a single copy probe on the short arm of the $Y$ with a 
homologous sequence in the middle of the long arm of the X chromosome ${ }^{3} ; 27 \mathrm{a}$ is a conserved and $\mathrm{Y}$ chromosome unique locus near to testis determining factor. ${ }^{4}$

\section{Results}

The figure (a) shows the results obtained with Taq1 digest and probe $27 \mathrm{a}$. Only track 2 (from a normal male control) showed any hybridisation. The lack of hybridisation makes it extremely unlikely that testis determining factor was present.

The figure (b) shows the results of hybridisation of Y-190 to a TaqI filter. Again only the track from the normal male control showed hybridisation. This

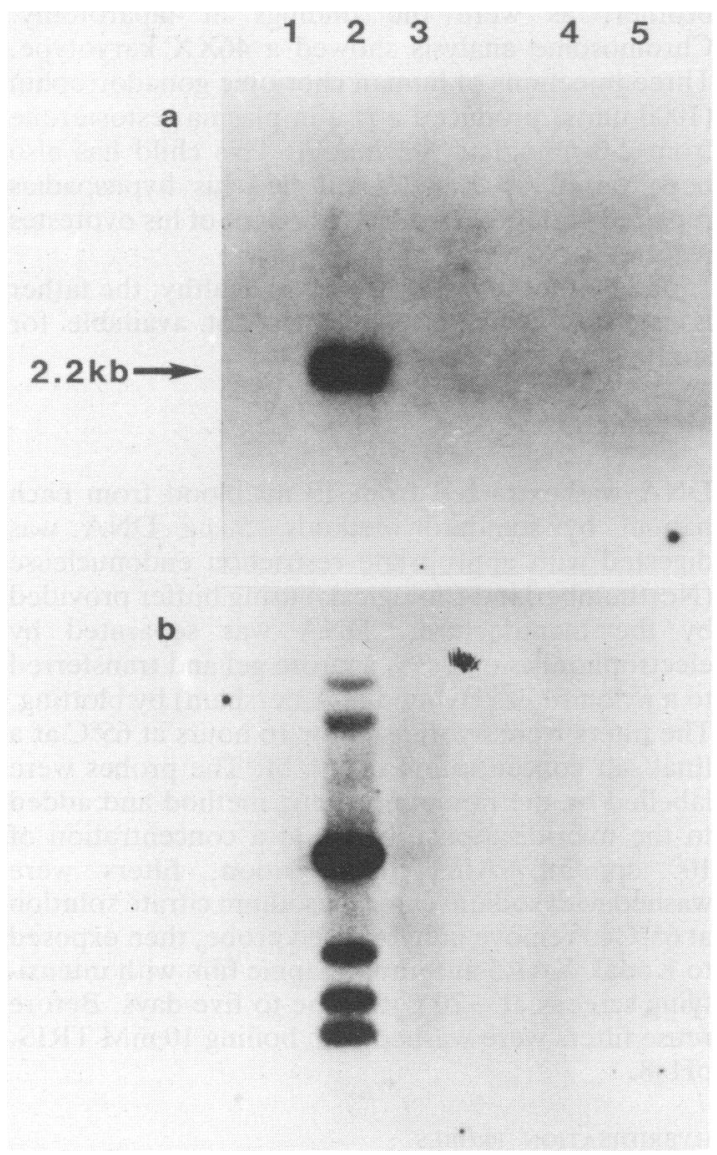

Figure (a) Autoradiograph of filter of TaqI digest hybridised with probe $27 a$. (b) Autoradiograph of filter of TaqI digested DNA hybridised with Y-190. Track $1=$ normal female; track 2 =normal male; track $3=$ mother; track 4 and $5=$ cases 1 and 2. confirms the lack of $\mathrm{Y}$ chromosome material in these children. It also rules out the possibility of mosaicism as the highly repetitive $\mathrm{Y}-190$ sequences would have been detected even if only $1 \%$ of $46 \mathrm{XY}$ cells had been present.

The other three probes gave the same results; this confirmed the above findings (results not shown).

\section{Discussion}

Most cases of true hermaphroditism are sporadic but there have been a few reports of familial hermaphroditism. ${ }^{56}$ As in our patients, some of these cases have been characterised by the presence of bilateral ovotestes, absent Mullerian derivatives, and 46XX karyotypes. In theory, sex chromosome mosaics or chimeras, translocations of part of the $Y$ chromosome to the $\mathrm{X}$ chromosome or an autosome, or an autosomal gene mutation could all lead to hermaphroditism. Mosaicism and chimerism are unlikely in our cases, however, because of the familial nature of the condition, the absence of cytogenetic evidence of a $46 \mathrm{XY}$ cell line in the gonadal fibroblast cultures, and the inability of the DNA probes to detect a $46 \mathrm{XY}$ cell line in peripheral lymphocytes. A DNA probe coding for a gonadal determining factor has recently been isolated. ${ }^{2}$ The probe, 27a, used here is extremely close to gonadal determining factor on the $\mathrm{Y}$ chromosome, and therefore a translocation of gonadal determining factor is unlikely in view of our inability to detect any 27 a fragments.

A gene mutation on an autosome or $\mathrm{X}$ chromosome is a much more likely explanation for our patients' familial hermaphroditism. Such a mutation could result in differentiation of a testis or ovotestis in a subject with a $46 \mathrm{XX}$ karyotype and in the absence of a Y chromosome. In the female heterozygous state the mutation would be insufficient to induce the indifferent gonad to become a testis but in the homozygous state ovotestes or a testis could differentiate. As there is a sequence closely related to gonadal determining factor on the $\mathrm{X}$ chromosome ${ }^{2}$ models have been suggested in which gonadal differentiation is determined by the dosage of factors from the $\mathrm{X}$ and $\mathrm{Y}$ chromosomes. ${ }^{7}$ Unusual families such as these will provide the material to test such hypotheses.

We wish to thank Dr Paul Goodfellow for help with the 27a probe Drs Sam Latt and Ulrich Muller for providing Y-190, and Professor MA Ferguson-Smith for providing GMGY7. SM and MER were supported by a Special Medical Development grant from the DHSS. 


\author{
References \\ 1 Affara NA, Ferguson-Smith MA, Magenis RE, et al. Mapping \\ the testis determinants by an analysis of $\mathrm{Y}$-specific sequences in \\ males with apparent $\mathrm{XX}$ and $\mathrm{XO}$ karyotypes and females with \\ XY karyotypes. Nucleic Acids Res 1987;15:7325-41. \\ 2 Page DC, Mosher R, Simpson EM, et al. The sex determining \\ region of the human $\mathrm{Y}$ chromosome encodes a finger protein. \\ Cell 1987;51:1091-104. \\ ${ }^{3}$ Pearson PL, Kidd KK, Willard HF. Report of the committee on \\ human gene mapping by recombinant DNA techniques. Cyto- \\ genet Cell Genet 1988;46,331-81. \\ 4 Pritchard CA, Goodfellow PJ, Goodfellow PN. Isolation of a \\ sequence which maps close to the human sex determining gene. \\ Nucleic Acids Res 1987;15:6159-69.
}

${ }^{5}$ Clayton GW, Darrel Smith J, Rosenberg HS. Familial true hermaphroditism in pre and post pubertal genetic females. Hormonal and morphological studies. Journal of Clinical Endocrinology 1958;18:1349-58.

6 Skordis NA, Stetka DG, MacGillivray MH, Greenfield SP. Familial 46XX males coexisting with familial 46XX true hermaphrodites in same pedigree. $J$ Pediatr 1987;110:244-8.

${ }^{7}$ Ferguson-Smith MA. Genes on the $\mathrm{X}$ and $\mathrm{Y}$ chromosomes controlling sex. Br Med J 1988;297:635-6.

Correspondence to Dr DB Grant, Hospital for Sick Children, Great Ormond Street, London WC1N 3JH.

Accepted 9 January 1989

\title{
Psychological care of survivors of a fire
}

\author{
T JAFFA* AND G SUPRAMANIAM $\dagger$ \\ ${ }^{*}$ Watford Child and Family Clinic, and †Watford General Hospital
}

SUMMARY A mother and daughter were the sole survivors of a house fire. Support, maintenance of the parent-child relationship, and monitoring and facilitating the grieving process in a way that was consistent with the developmental stages of the patients were the basis of management.

\section{Case report}

Four members of an Asian family of six died in a fire, started by a gas heater while they slept. They were the father, two daughters aged 11 and 2 , and a son aged 9. The mother and 7 year old daughter were admitted to the intensive care unit of the district general hospital. They were both suffering from extensive heat and inhalation injuries, and required ventilatory support-the mother for several hours, and the daughter for several days, during which she was sedated and paralysed.

The mother spoke little English, and so most communication was through her local authority social worker who spoke her language. Visitors told the mother that the other members of her family were in another hospital. Three days later she was told of their deaths. She seemed numbed, shed few tears, and asked no questions. Five days after the fire, the daughter had still not been told what had happened. She played quietly with nursing staff and often seemed frightened, but asked no questions about her burns, her presence in hospital, or the whereabouts of her father, brother, and sisters. She avoided contact with her mother. The mother's father was unable to be with her for another week. Physically, mother and daughter were well enough to be transferred from the intensive care unit.

\section{Psychological aspects of further management}

Because we thought that a multidisciplinary team approach would be the best way to help the patients, the paediatrician (GS), child psychiatrist (TJ), social worker, and nursing staff met regularly. These meetings helped us to acknowledge our feelings of hopelessness and our own memories of loss. We were then more able to separate these from our thinking about the needs of this mother and daughter.

We wished to support the relationship between the mother and daughter, so we ensured that when they were transferred they went to adjacent wards so that they could spend as much time as possible together. We also attempted to support their relationship by encouraging the mother in her role as a parent. There were aspects of hospital routine which made this difficult. The authority of a mother and the authority of hospital staff sit together somewhat uneasily, particularly when both the mother and her daughter are inpatients. In this case the mother's authority was undermined when the staff, despite the reluctance of the mother (who was suffering her own psychological injury), told the daughter about the fire and the deaths.

The daughter needed to know about the fire and deaths as soon as possible to end her uncertainty, to allow her to start grieving, and to avoid her hearing inaccurate accounts from other patients. It was 